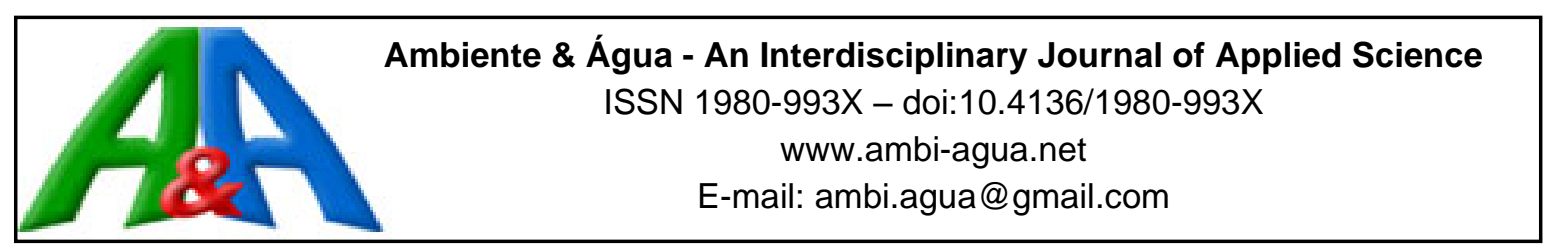

\title{
Changes in riparian forest cover from 1966 to 2017 along the Paraíba do Sul River between Jacareí and Queluz, São Paulo, Brazil
}

\author{
ARTICLES doi:10.4136/ambi-agua.2570
}

Received: 08 Oct. 2020; Accepted: 09 Nov. 2020

\author{
João Marcos Tourinho ${ }^{(D}$; Celso de Souza Catelani ${ }^{i}$; \\ Maria Cecília Barbosa de Toledo*iD
}

\begin{abstract}
Programa de Pós-Graduação em Ciências Ambientais (PPGCA). Universidade de Taubaté (UNITAU), Estrada Municipal Doutor José Luiz Cembranelli, n5000, CEP: 12081-010, Taubaté, SP, Brazil. E-mail: geo.marcos@bol.com.br, cscatelani@gmail.com *Corresponding author. E-mail: cecilia@unitau.br
\end{abstract}

\begin{abstract}
This study is based on the assumption that beginning with the passage of the Forest Code in 1965, which was revised by the law of 2012, the Permanent Preservation Area (PPA) of Paraíba do Sul River, PSR, is currently recuperated and preserved. In this context, the objective of this study was to: 1) conduct a temporal survey with respect to the rate of change of gains and losses of forest cover during the years 1966, 1977 and 2017; and,2) do a spatial analysis in relation to this rate of change. This study was conducted along the stretch of the PSR between the municipalities of Jacareí and Queluz. Maps were used from the Brazilian Institute of Geography and Statistics - IBGE (1964-1966), the Geographic and Cartographic Institute of the state of São Paulo - IGC-SP (1978) (IGC), and high resolution images from the Pléiades satellite (2017). For the spatial and temporal analyses of the study area, geoprocessing techniques were used to quantify the area occupied by forest in two: $100 \mathrm{~m}$ buffer strips of the PPA, and in buffer strips of $1,000 \mathrm{~m}$, starting from each bank of the river. With respect to forest cover, measurements of its total and average size, proportion, gain or loss, and distance between nearby fragments were made. The results indicate that, from the decade of the 1960s to 2017, forest cover grew from $5.3 \%$ to $21 \%$, and from $2 \%$ to $13 \%$ in the strips of 100 and 1,000 meters, respectively. With respect to areas registered from 1960, there was a reduction of 691 hectares, principally of large areas of remaining forest. However, a portion of this forest area was still present in 2017, but most of this forest was in the area $1,000 \mathrm{~m}$ from the riverbanks. These results will aid in the planning for establishment of priority areas for conservation of the riparian forest of the PSR. Through analysis of distances between forest fragments, empty spaces devoid of forest cover were identified, and in some cases these spaces were indicated as priority areas for recuperation. The results are discussed in the context of public policies and the periods of economic development that were drivers of landscape changes in the Paraíba do Sul Valley in the São Paulo region. In conclusion, the results demonstrate that the riparian forest of the PSR has slowly recuperated but is still far from being in compliance with current Brazilian legislation. This study will be an important aid in compliance activities conducted by public authorities in permanent preservation areas in the São Paulo PSR. An ample and refined survey of consolidated and fallow areas is suggested so that mitigation and compensation activities can be proposed for the PSR riparian forest that will promote the conservation of the quality of its water and biodiversity resources.
\end{abstract}

This is an Open Access article distributed under the terms of the Creative Commons Attribution License, which permits unrestricted use, distribution, and reproduction in any medium, provided the original work is properly cited. 
Keywords: cartography, environmental conservation, permanent preservation area, public policies, riparian forest.

\section{Alterações na cobertura florestal da mata ciliar ao Rio Paraíba do Sul, entre os anos de 1966 e 2017, no trecho Jacareí-Queluz, São Paulo, Brasil}

\section{RESUMO}

Este trabalho parte do pressuposto que a partir da promulgação do Código Florestal em 1965, reafirmada na revisão da Lei em 2012, a Área de Preservação Permanente (APP) do Rio Paraíba do Sul, PRS, encontra-se recuperada e preservada. Dessa forma, o presente trabalho teve como objetivo (1) realizar um levantamento temporal, compreendendo os anos de 1966, 1977 e 2017 e (2) um levantamento espacial, a partir das taxas de mudanças compreendendo ganhos e perdas na cobertura florestal. O trabalho foi realizado no trecho do RPS paulista entre os municípios de Jacareí a Queluz. Foram utilizadas as cartas do Instituto Brasileiro de Geografia e Estatística - IBGE (1964-1966), do Instituto Geográfico e Cartográfico do Estado de São Paulo - IGC-SP (1978) (IGC) e imagens de alta resolução do satélite Pléiades (2017). Para análise espacial e temporal da área de estudo, foram utilizadas técnicas de geoprocessamento quanto a área de ocupação da floresta em duas faixas: $100 \mathrm{~m}$ (Área de Preservação Permanente - APP) e $1000 \mathrm{~m}$ a partir de ambas as margens. Foram obtidas métricas quanto ao tamanho total e médio da cobertura florestal, proporção de ocupação das áreas de florestas, ganho/perda de áreas coberta por floresta e distância entre os fragmentos mais próximos. Os resultados revelaram que da década 60 até 2017 a cobertura florestal passou de $5,3 \%$ para $21 \%$ e de $2 \%$ para $13 \%$ nas faixas de 100 e 1000 metros, respectivamente. Quanto as áreas registradas em 1960, grande parte sofreu redução, uma perda de 691 hectares principalmente dos grandes remanescentes florestais. Entretanto, parte desses remanescentes florestais, permaneceram até 2017, porém, grande parte dessas áreas encontram-se na faixa de $1000 \mathrm{~m}$ de distância da margem. Esses resultados permitiram avaliar e sugerir áreas prioritárias para a conservação da mata ciliar ao RPS. A partir da análise das distâncias entre os fragmentos florestais, foram identificados espaços vazios, desprovidos de cobertura florestal e em alguns casos foram indicados como áreas prioritárias para recuperação. Os resultados evidenciaram que, lentamente, parte da mata ciliar ao RPS se recuperou, mas ainda está longe de satisfazer a legislação vigente no país. Esse trabalho pode ser útil para auxiliar a fiscalização das áreas de preservação permanente ao RPS paulista. Ao final considera-se necessário um amplo e minucioso levantamento das áreas de pousio e consolidadas para que sejam propostas ações de mitigação e compensação da mata ciliar ao Rio Paraíba do Sul e subsidiar a conservação da qualidade do recurso hídrico e da biodiversidade.

Palavras-chave: área de preservação permanente, cartografia, conservação ambiental, matas ciliares, políticas públicas.

\section{INTRODUCTION}

Forests located along the edges of water bodies, called riparian forest, represent an important part of the transition between aquatic and terrestrial ecosystems. The riparian forest has diverse functions, such as maintenance of the flux of energy and matter, which improves soil and water quality and promotes the preservation of biodiversity in aquatic and terrestrial ecosystems (Ewel et al., 2001; Lees and Peres, 2008; Miserendino et al., 2011). Despite their well-known importance, riparian forests are among the most degraded ecosystems due to human interference (Martins, 2001). The principal causes of degradation and/or elimination of riparian forests are, among others, (1) agriculture and cattle ranching activities wherein the 
landowner seeks to expand the cultivation area or pasture; (2) urbanization through illegal occupation; (3) lack of knowledge of the role of riparian forests, principally on the part of small-scale farmers who remove the forest to access the water; and (4) extraction of timber (Allan, 2004; Oliveira et al., 2011).

At the ecosystem level, the degradation and/or elimination of riparian forests is manifested in ecological losses, such as loss of biodiversity and nutrients, as well as in ecosystem services provided to local populations, such as harm to fishing resources and reduction in water quality (De Souza et al., 2013; Kelly et al., 2007; Lees and Peres, 2008; Likens et al., 1970; Tucci, 2008). In order to avoid the degradation of water and ecological resources of riparian forests, legislation such as the Brazilian Environmental Law (LAB) guarantees the preservation of the integrity of riparian forests. In this context, the Federal Forest Code (CF) has, for 55 years, (Brasil, 2012) recognized riparian forests as Permanent Preservation Areas (PPA), whether they are located in rural or urban areas (Magalhães and Pimentel, 2013)

In this way, riparian forests are part of the public management of the national territory at different levels of executive power that are responsible for managing this natural resource (Francisco et al., 2008). In this sense, it is the responsibility of public authorities and citizens to enforce compliance, conserve, and restore riparian forests (Machado, 2003), since any alteration, principally with respect to the width of forested land along the margins of bodies of water as established by law (Forest Code, Law 12.651, 25 May 2012), can reduce the efficiency of riparian forests and increase the risks of contamination of waters by agrochemicals, fertilizers, and the silting-up of water bodies (Kuntschik et al., 2011 ). From an administrative perspective, the width of the vegetation buffer strips in the PPA may vary between 30 and 500 metros according to the width of the bed of the body of water. The Forest Code (Brasil, 2012) also provides for the recuperation of riparian forests, and in this case the width of the vegetation strips may vary between 5 and $100 \mathrm{~m}$ as a function of the size of the property, the width of the riverbed, and the fallow cycles of nearby agricultural activities (the practice of incorporating a temporary interruption of agricultural, cattle ranching, or silvicultural activities for five years in order to enable the recuperation and renewal of the soil resource). However, the CF allows for the discontinuity of riparian forests in rural areas where agrosilvipastoral and agro/ecotourism activities were consolidated by July 22, 2008.

Brazil has continental dimensions and has regions that are in different stages of development (Araújo, 2017), wherein part of the territory suffered deforestation more than 50 years ago and the activities conducted in these areas are now consolidated (Gamba and Ribeiro, 2017), such as in the Atlantic Forest and Savannah biomes. In contrast, large portions of the Center-West and North regions of Brazil are confronting the challenges of conservation and agricultural development and tend to have their riparian forests conserved and/or recuperated in compliance with current environmental law. Paradoxically, the most developed and populated region, which therefore has the greatest demand for quality water resources is the one that has the highest degree of deforestation of riparian forests and consolidation of anthropogenic activities. In this way, the management and conservation of riparian forests is even more relevant in landscapes with a high degree of human impact (Goetz, 2006), such as is the case for the Paraíba do Sul Watershed in São Paulo (PSR).

In addition to the size of the territory, the complexity of the Brazilian hydrological system and the constant changes in human-impacted landscapes makes management and compliance efforts with respect to riparian forests an enormous challenge for public authorities (de Alcântara Laudares et al., 2014). In this context, besides mapping of vegetation cover in riparian zones, monitoring of the changes in these areas over time is also necessary (Goetz, 2006), and this will aid in guiding restoration activities and evaluation of the success of management actions and programs. Recent advances in remote sensing have the potential to substantially support monitoring and management of riparian zones. High resolution images are widely 
available, and these will aid in mapping and monitoring fine details of vegetation (Simões $e t$ $a l .$, 2002). There are government websites that provide access to cartographic documents, and multispectral, georeferenced orbital images. This supports making diagnoses and conducting systematic monitoring of the ecological state of riparian forests with the objective of attaining compliance with environmental public policies and with the demands of the larger society in general, which is an integral part of the management and compliance enforcement processes (Moura, 2016).

Despite the fact that the Paraíba do Sul River is located in the most developed and populous states in Brazil, little or almost nothing is known about the history and the current situation of its riparian forests since the enactment of the Federal Forest Code of 1965. In this context, the objective of this study was to: 1) conduct a temporal survey with respect to the rate of change of gains and losses of forest cover during the years 1966, 1977 and 2017;2) do a spatial analysis in relation to this rate of change; 3 ) identify areas of riparian forests that have remained intact from 1966 to 2017; and, 4) map areas without riparian forests with an emphasis on recuperation of these areas in compliance with the Forest Code, Law 12.651, of May 25, 2012.

\section{MATERIALS AND METHODS}

\subsection{Description of study area}

The Paraíba Valley is in the eastern region of the state of São Paulo. The selected stretch of the PSR used in this study is between coordinates $23^{\circ} 22^{\prime} 17^{\prime \prime} \mathrm{S}$ and $46^{\circ} 03^{\prime} 01^{\prime \prime} \mathrm{W}$ at its

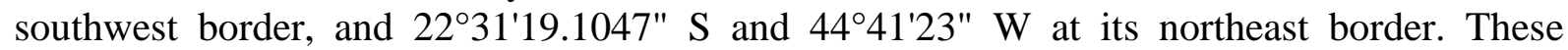
coordinates represent the political administrative limits of 16 municipalities: Jacareí, São José dos Campos, Caçapava, Taubaté, Tremembé, Pindamonhangaba, Roseira, Aparecida, Potim, Guaratinguetá, Lorena, Canas, Cachoeira Paulista, Cruzeiro, Lavrinhas and Queluz. All these municipalities are part of the Hydrographic Unit for Management of Hydrological Resources (UGRHI) 02, which is a component of regional management of hydrological resources (CETESB, 2019).

The climate in the region has hot and rainy summers with a dry winter. Average annual temperature is $21^{\circ} \mathrm{C}$, with an average for the warmest month above $24^{\circ} \mathrm{C}$ and that of the coldest month between $16^{\circ} \mathrm{C}$ and $17^{\circ} \mathrm{C}$. The months with the highest rainfall are January and February, with air relative humidity above $70 \%$ (Nimer, 1989) (Figure 1).

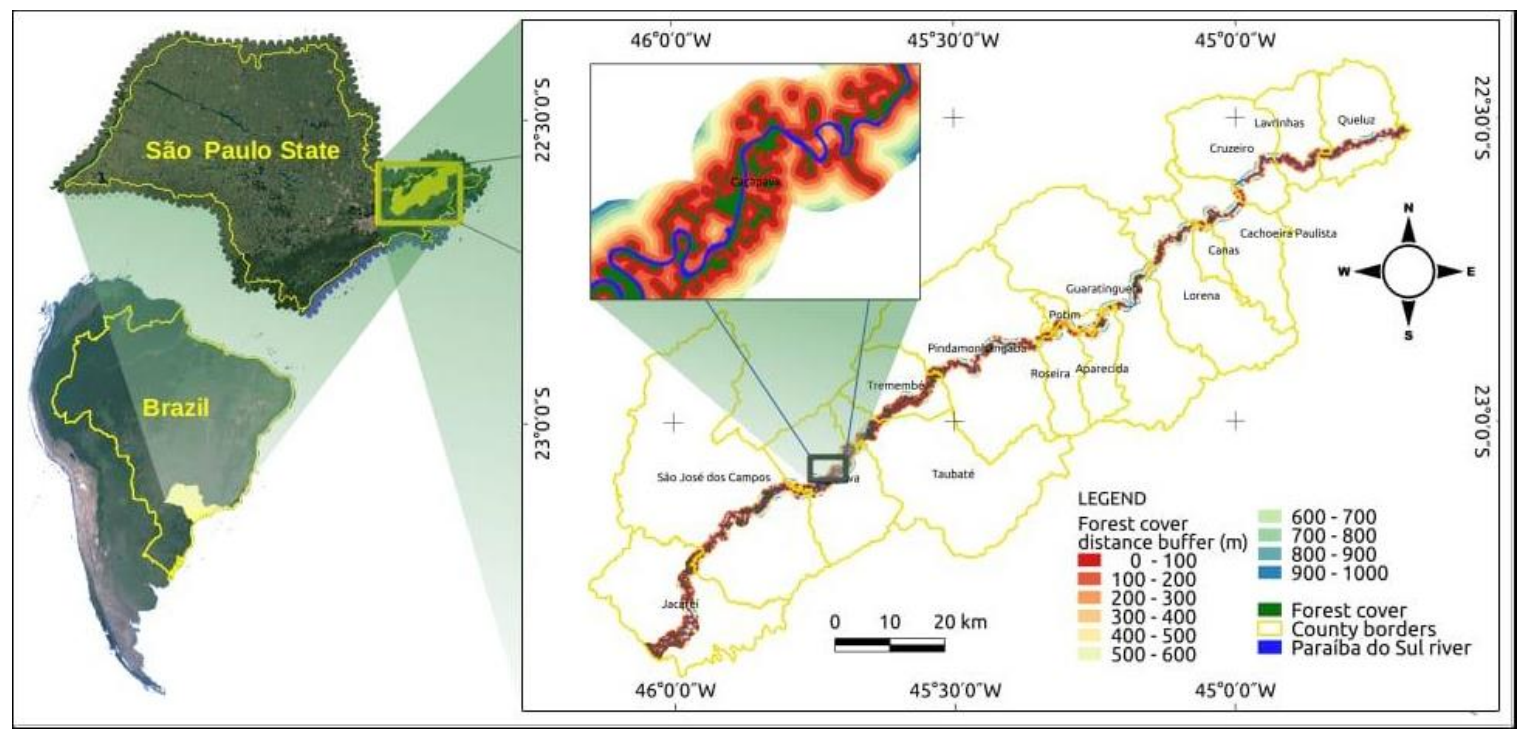

Figure 1. Location of the study area with emphasis on the distance among fragment forest maps and on the region of the middle course of the Paraíba do Sul River - CMPSR, state of São Paulo, Brazil. 


\subsection{Land use change analysis}

The methodology was based on identifying land-use change, as described by Grübler (1994), and Loveland et al. (1999), using remote sensing, geoprocessing, and statistical analysis of the results. Official cartographic data from the National Cartographic System (SCN), maintaining the original organization used by the national map to the millionth scale. Three databases were used to acquire secondary data to obtain information on land-use change with respect to classes of native forest cover: 1) ten maps or topographic sheets from the IBGE at a 1:50,000 scale which were directly accessed through the Geospatial Database of the Brazilian Army (BDGEx). The topographic maps from the IBGE were georeferenced following the original cartographic parameters of the $\mathrm{SCN}$, for which they were elaborated according to territorial projections of all the Units of the Federation (BDGEX, 2018). The years of the flights that generated the topographic maps are between 1964 and 1966; 2) Sixty-one topographic maps at a 1:10,000 scale that were made by the IGC. This material was produced through aerial surveys done in 1978 for the entire eastern region of the state of São Paulo by the Secretary of the Economy and Planning (SEPLAN). These cartographic data are currently available through the DATAGEO platform (http://datageo.ambiente.sp.gov.br) as part of the permanent collection of the Infrastructure of Environmental Spatial Data of the state of São Paulo (IDEASP); and, 3) eighteen orbital images from the Pleiades satellite that can be accessed for research in Brazil that are made available by official minutes no. 01/2015 and no. 02/2015 of the Ministry of Planning, Development, and Management. The images from Pleiades are available at a spatial resolution of 1.5 meters and are from February 2017. The set of images were cut and cropped into 61 rectangles assembled into a mosaic according to organizational areas used in the scale of maps made by the IGC $(1: 10,000)$ with total coverage of the study area.

Manipulation of cartographic data (topographic maps) and remote sensing (orbital images) was done using the geographic information systems (GIS) software QGIS Version 3.8 (QGIS Development Team, 2020), which included remote sensing and geoprocessing tools. After construction of the georeferenced database the study area was delimited. Initially, the margins of the Paraíba do Sul River between the municipalities of Jacareí and Queluz were digitalized along with the intersection of their limits, producing a polygon corresponding to a body of water. The study area was defined, starting at the limit of the polygon along the course of the river, by setting up buffers of 100 and 1,000 meters on each of the right and left margins. The $100 \mathrm{~m}$ buffer corresponds to the Permanent Preservation Area (PPA) as established and protected by law, and that of 1,000 m corresponds to the limits that were estimated to be under the influence of the entire ecosystem formed by the PSR, as, for example, the presence of old meanders. Therefore, the study area is composed of a 1,000 m wide buffer strip that includes the $100 \mathrm{~m}$ protected by law, and 900 additional meters without any specific legal protection (Figure 2).

For the spatial-temporal analysis, vectorization and polygonization of the areas of native forest cover was conducted, which encompassed all the successive stages of regeneration whether natural or anthropogenic. In this process, fragments 0.2 ha or larger were counted and measured in both the $100 \mathrm{~m}$ and $1,000 \mathrm{~m}$ buffers. The information was then superimposed and losses and gains in forest cover were calculated between the three evaluated years. Furthermore, an analysis was made of forest areas identified in 1966 which remained in 2017, and since these were the oldest forest areas registered in this interval, they were considered remnant forests (Figure 2). The forest areas were counted and divided into size classes of $>0.2$ to $<10 \mathrm{ha}, \geq 10$ to $<100$ ha, and $\geq 100$ ha. To describe the potential of conservation priority areas, the largest and oldest areas were considered.

The areas that were determined to be the most important priorities for recuperation were defined through an analysis of the distance between forest fragments. To this end, a raster plane (PI) was constructed with increasing distance $(\mathrm{m})$ starting at each fragment until reaching the 
limit of the study area, sliced into 100m strips, and then converted into a vector format.

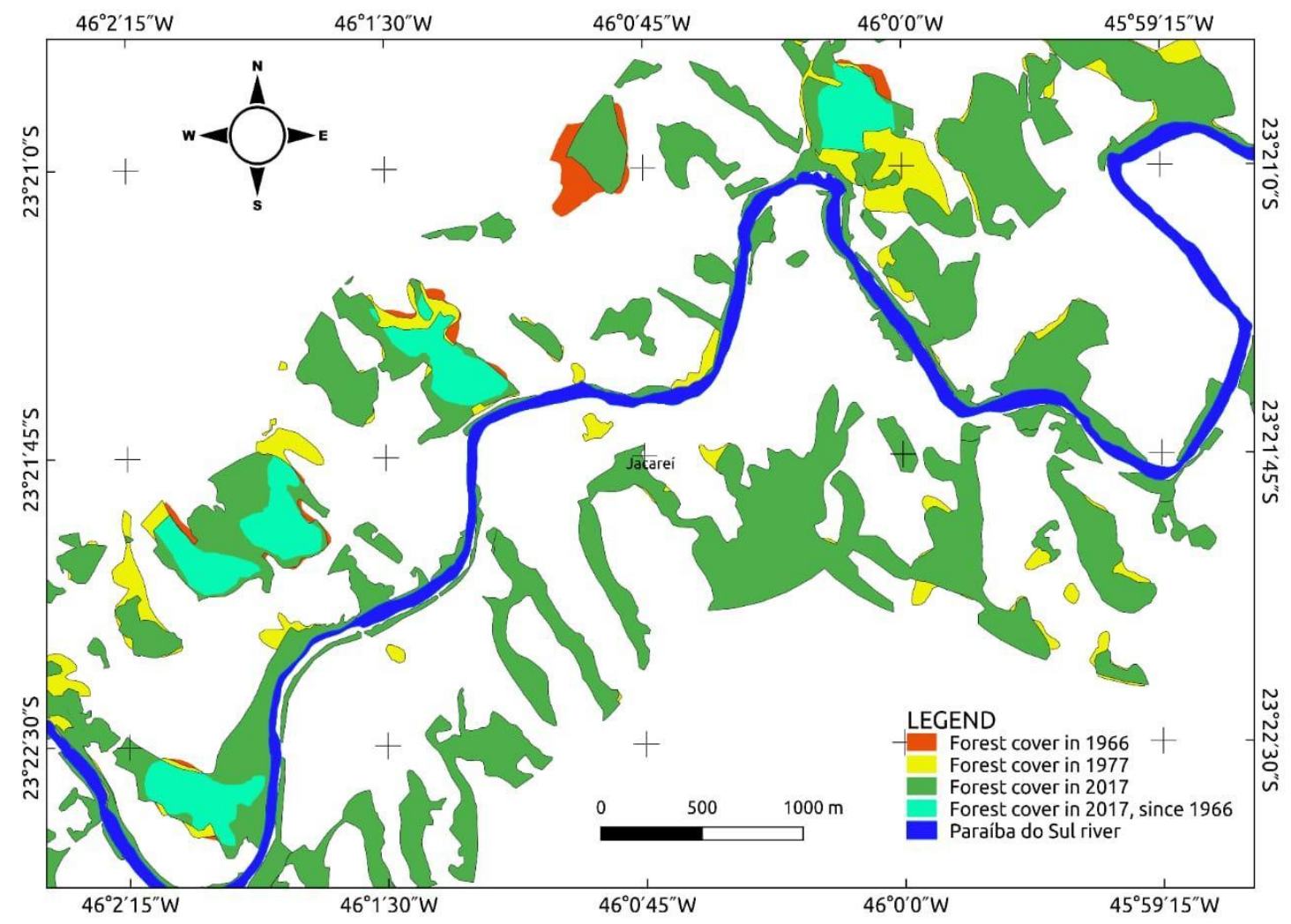

Figure 2. Cut out the study area corresponding to the Jacareí county, with the forest areas classified in 1966, 1977 and 2017 and the remaining forest areas since 1966.

Subsequently, another PI was created using consolidated urban areas scattered throughout the study area. By superimposing the distance of the PIs and those with the urban areas, a layer was generated that indicated areas that were devoid of vegetation and that were available for recuperation of the riparian forest in the PSR. Using as a base the results from the studies by Pardini et al. (2010) and Martensen et al. (2008), a distance of $200 \mathrm{~m}$ between fragments was established as the minimum which would allow for transit between them, according to the stepping-stone model (Correa Ayram et al., 2016). Therefore, areas with up to 200m to their nearest neighbor were not considered as isolated fragments, and therefore were not designated as being a priority for restoration.

The results were presented for total area (hectares) and proportion of areas occupied by forests (area covered by forest/ total buffer area/(100)) in each buffer strip and for each municipality. Additionally, descriptive statistics were calculated, including maximum and minimum values, averages $(\overline{\mathrm{x}})$, medians and standard deviations (SD). For the comparative analysis of the averages of the areas occupied by forest between years, a paired t-test was conducted at a probability level of $\alpha=5 \%$. All analyses were performed in R (R Core Team, 2018), using the "Stats v. 3.6.2" package. Graphics were done using the ggplot2 package (Wickham et al., 2016).

\section{RESULTS AND DISCUSSION}

The analysis of the PPA and $1,000 \mathrm{~m}$ buffer strips showed variation throughout time, with an increase in the total area of forest cover. In 1966, there were few fragments characterized by average and median values higher than those observed in 1977 and 2017. This occurred because there was an increase in the number of small fragments, principally in 1977, which can be 
observed as a function of the measurements of variability and the standard deviation (Table 1). This increase was greater in the $1,000 \mathrm{~m}$ buffer strip.

Table 1. Total values and descriptive statistics of the forest fragments in the PPA (100m) and 1000 meters buffers in the 1966, 1978, and 2017 years.

\begin{tabular}{lcccccc}
\hline \multirow{2}{*}{ Parameters } & \multicolumn{3}{c}{ Buffer - 100 m } & \multicolumn{3}{c}{ Buffer - 1000 m } \\
\cline { 2 - 7 } & 1966 & 1977 & 2017 & 1966 & 1977 & 2017 \\
\hline Number of fragments & 57.00 & 383.00 & 607.00 & 52.00 & 845.00 & 937.00 \\
Total area (ha) & 292.00 & 896.43 & $2,140.60$ & 954.03 & $3,389.47$ & $6,251.38$ \\
Minimum value (ha) & 0.03 & 0.02 & 0.02 & 0.04 & 0.00 & 0.03 \\
Maximum value (ha) & 16.23 & 22.29 & 37.50 & 96.13 & 89.28 & 161.43 \\
Mean & 5.13 & 2.57 & 3.52 & 18.35 & 4.01 & 6.67 \\
Median & 3.72 & 1.43 & 1.59 & 14.08 & 1.33 & 1.85 \\
Std. deviation (SD) & 4.40 & 3.54 & 5.28 & 17.01 & 7.91 & 13.95 \\
\hline
\end{tabular}

In 1966, forest cover along the margins of the PSR in the PPA buffer strip was 5.3\%, with a total area of 292 ha, and it was 2\% (954 ha total) in the 1,000 m buffer strip. According to Gamba and Ribeiro (2017), the decade of the 1950s until the middle of the 1960s was marked by intense deforestation incentivized for two principal motives: the lack of success of the 1932 Forest Code, and the developmentalist policies of the then President of the Republic Juscelino Kubistchek, which were continued by Getúlio Vargas. Furthermore, Gamba and Ribeiro (2017) state that the 1965 forest code was ignored during the entire period of the dictatorship. On the other hand, at the end of the XIX century the PSR watershed was the subject of many studies on the implantation of hydroelectric reservoirs, and among these were the Paraíbuna, Jaguari and Santa Branca Reservoirs (AGEVAP, 2010). Construction of these projects began between 1930 and 1960, but remained on hold during several decades due to the Second World War, and were reinitiated as a result of the Decree n. 30.626 of March 1, 1952, with the goals of producing electrical energy, controlling the flow of the river to avoid flooding, systematization of floodplain topography for irrigation and drainage, among other objectives, whose goal was supporting and improving agriculture. Even after the construction of the hydroelectric dams, which had as an objective the reduction of the intensity of changes in the water level in the floodplain area through greater control of the river flow, there were many complaints registered by residents of communities along the edge of the river due to the continued devastating floods and periods with extremely low levels of water, along with increasing pollution in the PSR. For this reason, in 1967 a special commission was created which aggregated the Constitution and Justice Commission and those of Transport, Communication, Public Works, and Justice into one commission, whose objective was to investigate the results of the Decree n. 30.626. At that point, more than 15 years had passed since the construction of the reservoirs and the problems with the river had persisted. The report of the National Department of Public Sanitation Works (DNOS) was annexed to the legal documentation provided to the special commission created by the Chamber of Federal Deputies. The DNOS, together with the Department of Waters and Electrical Energy of the state of São Paulo (DAEE), prepared a blueprint to adjust the plans to modify the containment strategies of the PSR along the stretch from Jacareí to Cachoeira 
Paulista, which was approved in 1952 and executed starting in 1957 (Brasil, 1967; Devide et al., 2014). Furthermore, this report comments on the intense deforestation in the Paraíba Valley in São Paulo as one of the problems that was occurring in a chaotic manner since the period of the Second Empire in Brazil, and that this could be contributing to aggravation of problems in the region. Therefore, it is highly probable that the elimination of riparian forests occurred before the proposal to modify the containment strategies of the PSR, but in either case this process contributed to the removal of riparian forests along the entire recuperated stretch of river.

In 1977, there were 362 fragments which resulted in an increase of $261 \%$ in the area covered by forest. As a function of this increase, the total area of riparian forest changed from $5.3 \%$ to $15.8 \%(\mathrm{t}=3.44 ; \mathrm{p}=0.001)$. The area of riparian forest between 1966 and 1977 in the $100 \mathrm{~m}$ buffer strips was significantly smaller $(\mathrm{t}=2.81 ; \mathrm{p}=0.008)$ in 1966 . In the $1,000 \mathrm{~m}$ buffer zones, there was an increase of 355\%, with 954 ha in 1966 and 3,389.2 ha in $1977(\mathrm{t}=-4.77 ; \mathrm{p}=$ $0.000)$. Despite the large numerical increase in forest cover, proportionally the total area in the $1,000 \mathrm{~m}$ buffers was $2.8 \%$ in 1966 , and $10.1 \%$ in $1977(\mathrm{t}=-8.86 ; \mathrm{p}=0.000)$.

As related by Roriz and Fearnside (2015) and Gamba and Ribeiro (2017), during 19651977 there were no financial incentives in place to aid landowners comply with the 1965 Forest Code. It was with the creation of the National Environmental Policy in 1981 and the Federal Constitution of 1988 that conservation of riparian forests began to gain greater attention. However, the existence of these laws did not explain per se the increase in riparian forests in some municipalities, such as Jacareí, São José dos Campos, Caçapava and Pindamonhangaba, which had increased $>100 \%$ in the $100 \mathrm{~m}$ buffer, and 100 to $>300 \%$ in the $1,000 \mathrm{~m}$ buffer (Tables 2 and 3). According to Devide et al. (2014), the decade of the 1970s was marked by intense industrial and transport activities, principally in the cities located near the beginning of the middle course of the Paraíba Valley, which became a strong economic center. In contrast, the situation was different for the cities located near the final part of the middle course of the Paraíba Valley, called the "historical region" of the valley, between the mountains of Bocaina and Mantiqueira to the east, and encompassing Arapeí, Areias, Bananal, Queluz, São José do Barreiro and Silveiras. These municipalities maintained economies based on the cycle of coffee cultivation and became poorer, and this was a period when a part of the population migrated to the new economic center. In this way, variation in economic cycles also contributed to the formation of new scenarios and changes in rural landscapes as well as in urban areas.

From the scenario observed in 1977 to that in 2017, a span of 40 years, there was great change in the two analyzed buffer zones. The $100 \mathrm{~m}$ buffer in the forest increased from 878 ha in 1977 to $2,173.2$ ha in $2017(\mathrm{t}=-5.26$; $\mathrm{p}=0.000)$. However, in this buffer the percentage of forest cover increased only from $16 \%$ to $23.3 \%$, which was not significant $(t=-1,88 ; \mathrm{p}=0.08)$. In 2017, in the $1,000 \mathrm{~m}$ buffer, the change was an increase of $13 \%$ compared to $1977(\mathrm{t}=-4.58$; $\mathrm{p}=0.000)$ with a total area of 3,800 ha, with the difference between 1977 and 2017 being 1,365 ha $(\mathrm{t}=-3.2 ; \mathrm{p}=0.006)$.

The municipalities that most increased their area of riparian forests in the PSR were the same ones that had the largest proportions in 1966 and 1977, which were Jacareí, São José dos Campos and Caçapava, also including Tremembé, which had a >100 ha increase in riparian forest. In the $1000 \mathrm{~m}$ buffer zone, riparian forest area increased most in the municipalities of Jacareí (880 ha), São José dos Campos (636 ha) and Tremembé (520 ha). The CETESB (2019), in its annual survey on the situation of riparian forests together with the principal rivers in the state of São Paulo, also recognized a large increase in the number of forest fragments in the PPAs during the last 50 years. The CETESB data corroborate those of the current study and demonstrate that an increase in riparian forests occurred at the scale of the entire state. Despite this increase having occurred during the last 51 years, the average proportion of forest cover in the buffer zone protected by law (PPA), was, on average, $22 \pm 8.9 \%$. 
Table 2. Total values in hectare (ha) of the PPA (100 meters) buffers, forest cover area (ha) and forest cover by area (\%) of each county in the years of 1966 , 1978, 2017, and the gain in all studied periods.

\begin{tabular}{|c|c|c|c|c|c|c|c|c|c|}
\hline \multirow{3}{*}{ County } & \multirow{3}{*}{$\begin{array}{c}\text { Buffer } 100 \\
\text { (ha) }\end{array}$} & \multicolumn{2}{|c|}{1966} & \multicolumn{2}{|c|}{1978} & \multicolumn{2}{|c|}{2017} & \multirow{2}{*}{\multicolumn{2}{|c|}{$\begin{array}{l}\text { 1966-2017 } \\
\text { Total gain }\end{array}$}} \\
\hline & & \multirow{2}{*}{$\begin{array}{l}\text { Forest cover } \\
\text { (ha) }\end{array}$} & \multirow{2}{*}{$\begin{array}{l}\text { Forest cover } \\
(\%)\end{array}$} & \multirow{2}{*}{$\begin{array}{l}\text { Forest cover } \\
\text { (ha) }\end{array}$} & \multirow{2}{*}{$\begin{array}{c}\text { Forest cover } \\
(\%)\end{array}$} & \multirow{2}{*}{$\begin{array}{l}\text { Forest cover } \\
\text { (ha) }\end{array}$} & \multirow{2}{*}{$\begin{array}{c}\text { Forest cover } \\
(\%)\end{array}$} & & \\
\hline & & & & & & & & ha & $\%$ \\
\hline Aparecida & 159.70 & 31.36 & 19.64 & 27.82 & 37.06 & 17.29 & 10.83 & 45.11 & 143.85 \\
\hline Caçapava & 614.83 & 107.31 & 17.45 & 63.00 & 27.70 & 107.18 & 17.43 & 170.18 & 158.59 \\
\hline Cachoeira Paulista & 280.06 & 2.04 & 0.73 & 26.13 & 10.06 & 56.29 & 20.10 & 82.42 & $4,040.20$ \\
\hline Canas & 30.65 & 0.00 & 0.00 & 0.00 & 0.00 & 6.49 & 21.17 & 6.49 & \\
\hline Cruzeiro & 262.28 & 0.00 & 0.00 & 4.38 & 1.67 & 40.70 & 15.52 & 45.08 & \\
\hline Guaratinguetá & 298.99 & 1.50 & 0.50 & 26.72 & 9.44 & 56.11 & 18.77 & 82.83 & $5,522.00$ \\
\hline Jacareí & 740.58 & 13.23 & 1.79 & 40.28 & 7.22 & 192.44 & 25.99 & 232.72 & $1,759.03$ \\
\hline Lavrinhas & 259.77 & 0.00 & 0.00 & 10.31 & 3.97 & 35.98 & 13.85 & 46.29 & \\
\hline Lorena & 289.97 & 0.00 & 0.00 & 24.76 & 8.54 & 98.90 & 34.11 & 123.66 & \\
\hline Pindamonhangaba & 557.56 & 47.69 & 8.55 & 102.63 & 26.96 & 45.26 & 8.12 & 147.89 & 310.11 \\
\hline Potim & 128.41 & 18.50 & 14.41 & 37.19 & 43.37 & -4.70 & -3.66 & 32.49 & 175.62 \\
\hline Queluz & 362.28 & 6.25 & 1.73 & 13.85 & 5.55 & 41.54 & 11.47 & 55.39 & 886.24 \\
\hline Roseira & 120.61 & 0.00 & 0.00 & 62.95 & 52.19 & 16.09 & 13.34 & 79.04 & \\
\hline São José dos Campos & 792.55 & 17.80 & 2.25 & 161.83 & 22.66 & 190.10 & 23.99 & 351.93 & $1,977.13$ \\
\hline Taubaté & 255.93 & 39.56 & 15.46 & 18.40 & 22.65 & 97.45 & 38.08 & 115.85 & 292.85 \\
\hline Tremembé & 392.55 & 7.54 & 1.92 & 63.19 & 18.02 & 167.21 & 42.60 & 230.40 & $3,055.70$ \\
\hline Total & $5,546.70$ & 292.78 & 5.28 & 683.43 & 17.60 & $1,164.33$ & 20.99 & $1,880.70$ & 642.36 \\
\hline
\end{tabular}


Table 3. Total values in hectare (ha) of the 1000 meters buffers, forest cover area (ha) and forest cover by area (\%) of each county in the years of 1966 , 1978,2017 , and the gain in all studied periods.

\begin{tabular}{|c|c|c|c|c|c|c|c|c|c|}
\hline \multirow{3}{*}{ County } & \multirow{3}{*}{$\begin{array}{c}\text { Buffer } 1000 \\
\text { (ha) }\end{array}$} & \multicolumn{2}{|c|}{1966} & \multicolumn{2}{|c|}{1977} & \multicolumn{2}{|c|}{2017} & \multirow{2}{*}{\multicolumn{2}{|c|}{$\frac{1966-2017}{\text { Total gain }}$}} \\
\hline & & \multirow{2}{*}{$\begin{array}{l}\text { Forest cover } \\
\text { (ha) }\end{array}$} & \multirow{2}{*}{$\begin{array}{l}\text { Forest cover } \\
(\%)\end{array}$} & \multirow{2}{*}{$\begin{array}{c}\text { Forest cover } \\
\text { (ha) }\end{array}$} & \multirow{2}{*}{$\begin{array}{l}\text { Forest cover } \\
(\%)\end{array}$} & \multirow{2}{*}{$\begin{array}{l}\text { Forest cover } \\
\text { (ha) }\end{array}$} & \multirow{2}{*}{$\begin{array}{l}\text { Forest cover } \\
(\%)\end{array}$} & & \\
\hline & & & & & & & & ha & $\%$ \\
\hline Aparecida & $1,801.72$ & 32.55 & 1.81 & 63.53 & 5.33 & 79.32 & 7.93 & 110.30 & 338.89 \\
\hline Caçapava & $4,347.08$ & 242.82 & 5.59 & 207.81 & 10.37 & 384.88 & 13.63 & 349.88 & 144.09 \\
\hline Cachoeira Paulista & $2,308.01$ & 15.17 & 0.66 & 68.76 & 3.64 & 102.34 & 7.41 & 155.93 & $1,028.08$ \\
\hline Canas & $1,115.23$ & 0.00 & 0.00 & 0.00 & 0.00 & 13.27 & 1.19 & 13.27 & \\
\hline Cruzeiro & $2,405.36$ & 0.00 & 0.00 & 69.63 & 2.89 & 19.67 & 3.71 & 89.31 & \\
\hline Guaratinguetá & $2,624.51$ & 26.07 & 0.99 & 118.96 & 5.53 & 115.62 & 8.94 & 208.51 & 799.71 \\
\hline Jacareí & $6,498.35$ & 164.06 & 2.52 & 323.44 & 7.50 & 880.89 & 18.53 & $1,040.27$ & 634.07 \\
\hline Lavrinhas & $2,097.42$ & 46.00 & 2.19 & 99.90 & 6.96 & 129.13 & 10.92 & 183.03 & 397.87 \\
\hline Lorena & $2,558.62$ & 17.12 & 0.67 & 56.11 & 2.86 & 191.20 & 9.67 & 230.19 & $1,344.60$ \\
\hline Pindamonhangaba & $4,378.33$ & 228.61 & 5.22 & 322.63 & 12.59 & 197.87 & 11.89 & 291.89 & 127.68 \\
\hline Potim & $1,698.51$ & 6.01 & 0.35 & 109.12 & 6.78 & 0.99 & 6.48 & 104.10 & $1,732.44$ \\
\hline Queluz & $2,638.33$ & 47.26 & 1.79 & 150.69 & 7.50 & 181.71 & 12.60 & 285.14 & 603.36 \\
\hline Roseira & $1,569.50$ & 0.00 & 0.00 & 106.94 & 6.81 & 78.34 & 11.80 & 185.28 & \\
\hline São José dos Campos & $6,248.78$ & 56.71 & 0.91 & 488.04 & 8.72 & 636.12 & 17.99 & 1067.45 & $1,882.24$ \\
\hline Taubaté & $2,203.57$ & 47.92 & 2.17 & 68.60 & 5.29 & 268.11 & 15.28 & 288.78 & 602.59 \\
\hline Tremembé & $3,363.99$ & 23.69 & 0.70 & 181.12 & 6.09 & 520.63 & 20.86 & 678.06 & $2,862.67$ \\
\hline Total & 47,857.31 & 953.99 & 1.99 & $2,435.30$ & 7.08 & $3,800.09$ & 13.03 & $5,281.41$ & 553.61 \\
\hline
\end{tabular}


These results show that most fragments are small, between 0.2 and 10 ha, principally in the $100 \mathrm{~m}$ buffer strip and in the 1978 and 2017 years (Figure 3A and B). On the other hand, the largest fragments, between 10 and 100 hectares, were in both buffers in 2017. At the end of the 1990s, the Secretary of the Environment published resolution SMA n. 28/99, which established environmental zoning for mining in floodplain areas of the Paraíba do Sul River in the municipalities of Jacareí, São José dos Campos, Caçapava, Taubaté, Tremembé and Pindamonhangaba. The extraction of sand was permitted along this stretch of the river in agreement with SMA resolution n ${ }^{\circ}$ 03/99 (São Paulo, 1999a). This resolution sought to maintain the integrity of environmental protection zones and provided safeguards to protect the ecosystem formed by the Paraíba do Sul River through preservation of remnant vegetation, especially that associated with abandoned meanders and floodplain conservation zones. With respect to abandoned meanders, this law may have been the element that most contributed to the recuperation of forest area in the $100 \mathrm{~m}$ buffer zone as well as outside of it.
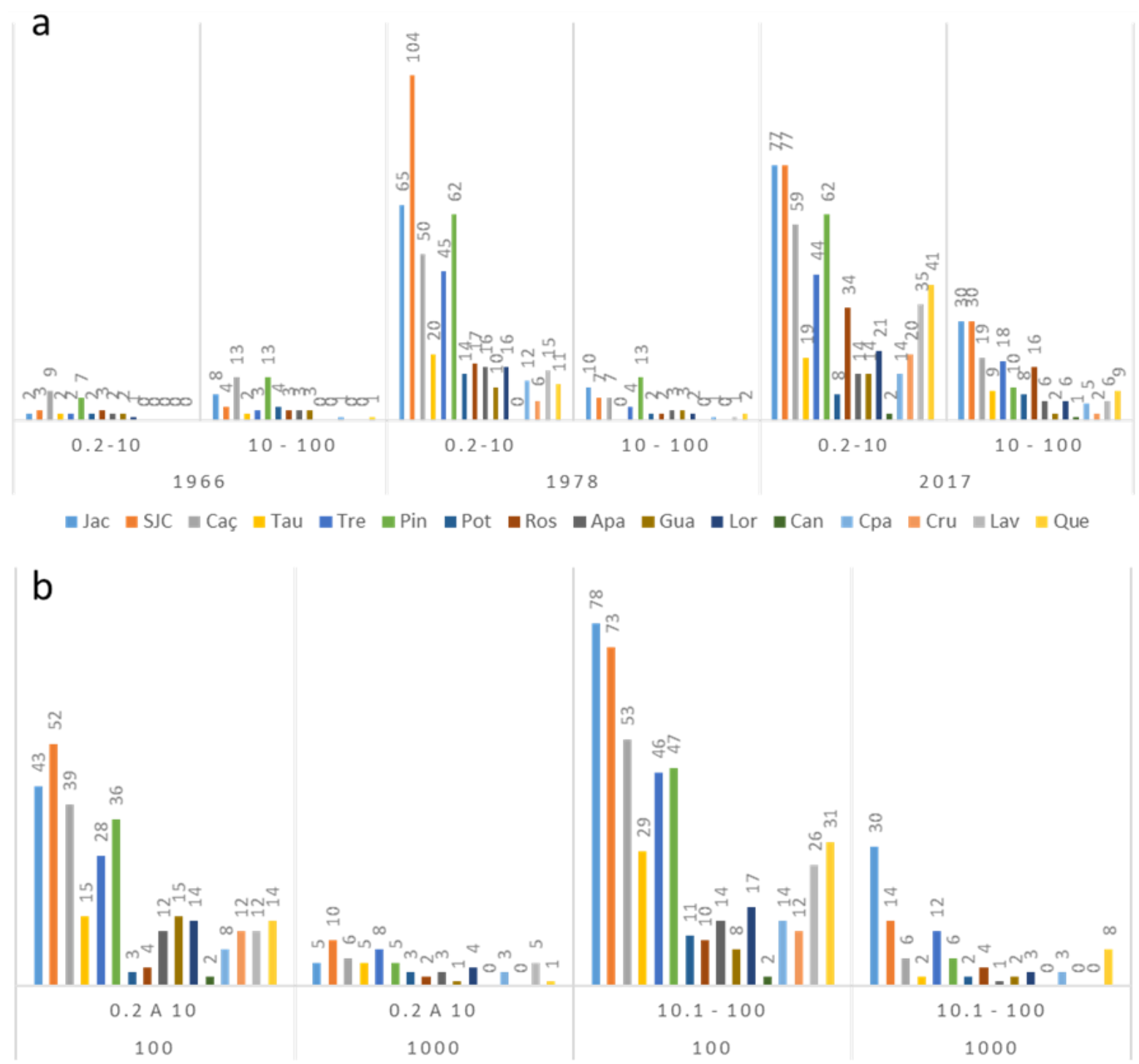

Figure 3. Distribution of number of fragments by class of size ( 0.2 to 10 ha and 10 to 100 ha) in three years (A) and in the PPA and 1000 meters buffers (B) to all municipalities of CMRPS. Legend: Jac: Jacareí, SJC: São José dos Campos, Caç: Caçapava, Tau: Taubaté, Tre: Tremembé, Pin: Pindamonhangaba, Pot: Potim, Ros: Roseira, Apa: Aparecida, Gua: Guaratinguetá, Lor: Lorena, Can: Canas, Cpa: Cachoeira Paulista, Cru: Cruzeiro, Lav: Lavrinhas, Que: Queluz.

SMA resolution n. 28/99 (São Paulo, 1999b), which regulates sand extraction in the PSR 
valley, has a direct effect on the conservation and protection of the entire area of influence of the Paraíba do Sul River ecosystem, including the areas protected by law such as PPAs and legal reserves, and has as its objective the development of compatible urban, agriculture, and preservation uses. The results from the current study undoubtedly demonstrate that legislation has influenced the process of recuperation of riparian forests in the PSR, principally during the last two decades.

However, there were still large losses of remnant areas that existed in 1966. The results show that the area in 1966 was small (5.8\%) and lost 27.5\% (-691.4 ha), and currently contains just $1.6 \%$ of the remnant areas that existed in 1966. Table 4 shows that the largest remnant areas were those that suffered the largest reductions, such as those in Jacareí, Caçapava and Pindamonhangaba.

Recent studies have shown the importance of old-growth ( $>90$ years) forests, which are in the late stages of succession and have preserved important characteristics such as greater diversity of vegetation species, more dead and emergent trees, and trees with larger diameters, which provide nesting sites in hollow cavities. These characteristics are responsible for the preservation of species from different groups such as microorganisms, insects, amphibians, and birds that live only in mature forests (Peña et al., 2005; Audino et al., 2014; Díaz-García et al., 2017; Cadieux and Drapeau, 2017), and this guarantees the sustainability of the forest. In this context, forests that are larger in stature and more mature will aid in the recuperation of a landscape through the colonization of nearby fragments that are in the initial stages of succession (Foppen et al., 2000). Using this theoretical framework as a base, the remnant areas located in the municipalities of Caçapava, Jacareí, Pindamonhangaba, São José dos Campos and Queluz are probably the most ecologically relevant for riparian forest restoration in the PSR. Many of these remnant areas are in the 1,000 m buffer zones and are therefore outside of the legal limits established for conservation and recuperation (Figure 3) and for this reason require special attention.

Table 4. Losses in area of the remaining fragments recorded from 1966 to 2017, in the PPA range of the VPR.

\begin{tabular}{ccccc}
\hline Counts & $\mathbf{1 9 6 6}$ to 1978 & $\mathbf{1 9 7 8}$ to 2017 & Change area (ha) & Remaning (\%) \\
\hline Aparecida & 32.55 & 0.18 & -32.37 & 0.54 \\
Caçapava & 242.82 & 48.31 & -194.50 & 19.90 \\
Cachoeira Paulista & 15.17 & 13.56 & -1.61 & 89.40 \\
Canas & 0.00 & 0.00 & 0.00 & 0.00 \\
Cruzeiro & 0.00 & 0.00 & 0.00 & 0.00 \\
Guaratinguetá & 26.07 & 0.00 & -26.07 & 0.00 \\
Jacareí & 164.06 & 75.57 & -88.49 & 46.06 \\
Lavrinhas & 46.00 & 0.00 & -46.00 & 0.00 \\
Lorena & 17.12 & 0.00 & -17.12 & 0.00 \\
Pindamonhangaba & 228.61 & 70.57 & -158.04 & 30.87 \\
Potim & 6.01 & 0.04 & -5.97 & 0.59 \\
Queluz & 47.26 & 22.59 & -24.67 & 47.79 \\
Roseira & 0.00 & 0.00 & 0.00 & 0.00 \\
São José dos Campos & 56.71 & 24.11 & -32.61 & 42.51 \\
Taubaté & 47.92 & 7.66 & -40.27 & 15.98 \\
Tremembé & 23.69 & 0.00 & -23.69 & 0.00 \\
\hline Total & $\mathbf{9 5 3 . 9 9}$ & $\mathbf{2 6 2 . 5 8}$ & -691.41 & 27.52 \\
\hline
\end{tabular}


However, to stimulate the recuperation of the ecosystems of the PSR, it is not enough to simply maintain mature forests. The restoration of gaps in riparian forests must also be made a priority since these gaps impede efficient functioning of these forests as ecological corridors. The results from the mapping of the distances between the fragments in the $100 \mathrm{~m}$ and $1,000 \mathrm{~m}$ buffer zones showed that the largest gaps, between 3,000 and 4,000 m without the presence of riparian forest, are located in the historical CMPSR municipalities, with Cruzeiro and Queluz having the largest distances, above 1,000m. Kronka et al. (2005), related that the municipalities of Jacareí, Pindamonhangaba, Potim, Guaratinguetá, Cachoeira Paulista, Cruzeiro and Queluz were, 15 years ago, priorities for the recomposition of fragments of their riparian forests in PPAs. In the same year, a decree by the state of São Paulo (n 61.183, March 20, 2015; São Paulo, 2015), created a management committee called the "Program of Incentives to Recuperate Riparian Forests", whose objective was to establish a system of tools that would support riparian forest conservation and recuperation programs in the state. After more than 10 years, in the current scenario, the municipalities of Cruzeiro and Queluz are still considered priorities.

\section{CONCLUSIONS}

Since the creation of the Forest Code in 1965, the riparian forests in the PSR have maintained just $5.3 \%$ of their forest cover, principally formed by large fragments that surpass the limits of the permanent preservation areas as established by law. There has been an increase in the area of forest cover during the last 51 years, but this increase was only $21 \%$, and resulted not just from public policies but mostly from the different scenarios of economic development that occurred during this period. The results of this study also show that remnant areas from the 1960s should be conserved since they have relevant ecological interest, principally in the support of forest restoration in municipalities that have not made much progress with respect to compliance with legislation. In this context, it is important to determine which areas are critical for recuperation and that will require compensation and mitigation processes as part of the solution. These plans should not be developed only at the state level but should also be integrated at the level of municipal management, even if in a complementary manner.

\section{ACKNOWLEDGMENTS}

The authors are especially grateful to Teacher Ruth Leodório Tourinho, in memoriam.

\section{REFERENCES}

\section{AGEVAP. Relatório técnico sobre a situação dos reservatórios com subsídios para ações de melhoria da gestão na bacia do rio Paraíba do Sul. São Paulo, 2010. 178p.}

ALLAN, J. D. Landscapes and riverscapes: the influence of land use on stream ecosystems. Annual Review of Ecology, Evolution, and Systematics, v. 35, n. 1, p. 257-284, 2004. https://doi.org/10.1146/annurev.ecolsys.35.120202.110122

ARAÚJO, S. M. V. G. de. Desafios do IBAMA para a gestão ambiental no Brasil. Boletim Regional, Urbano e Ambiental, v. 16, p. 117-119, 2017.

AUDINO, L. D.; LOUZADA, J.; COMITA, L. Dung beetles as indicators of tropical forest restoration success: Is it possible to recover species and functional diversity? Biological Conservation, v. 169, p. 248-257, 2014. https://doi.org/10.1016/j.biocon.2013.11.023

BDGEx. Carta topográfica vetorial de Belém -SA-22-X-D-III. Escala 1:100.000. Available at: https://bdgex.eb.mil.br/mediador/. Access: 03 Oct. 2018. 
BRASIL. Câmara dos Deputados. Projeto no 51 de 1967. Institui comissão especial para estudar o aproveitamento dos recursos do Vale do Paraíba e dá outras providências. 29 março $1967 . \quad$ Available at: https://www.camara.leg.br/proposicoesWeb/prop_mostrarintegra;jsessionid=CDB2CA1 B941FFBB9D94A245B9998A893.proposicoesWebExterno1?codteor=1193756\&filena me=Dossie+-PL+51/1967. Access: 15 Sep. 2020.

BRASIL. Presidência da República. Decreto $n^{\circ} 12.651$, de 25 de maio de 2012. Dispõe sobre a proteção da vegetação nativa; altera as Leis $n^{\circ}$ s 6.938 , de 31 de agosto de 1981, 9.393, de 19 de dezembro de 1996, e 11.428, de 22 de dezembro de 2006; revoga as Leis n's 4.771, de 15 de setembro de 1965, e 7.754, de 14 de abril de 1989, e a Medida Provisória ${ }^{\circ}$ 2.166-67, de 24 de agosto de 2001; e dá outras providências. Diário Oficial [da] União: seção 1, Brasília, DF, 28 maio 2012.

CADIEUX, P.; DRAPEAU, P. Are old boreal forests a safe bet for the conservation of the avifauna associated with decayed wood in eastern Canada? Forest Ecology and Management, v. 385, p.127-139, 2017. https://doi.org/10.1016/j.foreco.2016.11.024

CETESB. Qualidade das águas interiores no estado de São Paulo 2018. 2019. Available at: https://cetesb.sp.gov.br/aguas-interiores/wp-content/uploads/sites/12/2019/10/Relatóriode-Qualidade-das-Águas-Interiores-no-Estado-de-SP-2018.pdf. Access: 05 Oct. 2019.

CORREA AYRAM, C. A.; MENDOZA, M. E.; ETTER, A.; SALICRUP, D. R. P. Habitat connectivity in biodiversity conservation: A review of recent studies and applications. Progress in Physical Geography, v. 40, n. 1, p. 7-37, 2016 https://doi.org/10.1177\%2F0309133315598713

DE ALCÂNTARA LAUDARES, S. S.; DA SILVA, K. G.; BORGES, L. A. Cadastro Ambiental Rural: uma análise da nova ferramenta para regularização ambiental no Brasil. Desenvolvimento e Meio Ambiente, v. 2014. http://dx.doi.org/10.5380/dma.v31i0.33743

DE SOUZA, A. L. T. D.; FONSECA, D. G.; LIBÓRIO, R. A.; TANAKA, M. O. Influence of riparian vegetation and forest structure on the water quality of rural low-order streams in SE Brazil. Forest Ecology and Management, v. 298, p. 12-18, 2013. https://doi.org/10.1016/j.foreco.2013.02.022

DEVIDE, A. C. P.; CASTRO, C. M. de; RIBEIRO, R. de L. D.; ABBOUD, A. C. de S.; PEREIRA, M. G.; RUMJANEK, N. G. História Ambiental do Vale do Paraíba do Sul, Brasil. Revista Biociências, v. 20, n. 1, p. 12-29, 2014.

DÍAZ-GARCÍA, J. M.; PINEDA, E.; LÓPEZ-BARRERA, F.; MORENO, C. E. Amphibian species and functional diversity as indicators of restoration success in tropical montane forest. Biodiversity and Conservation, v. 26, n. 11, p. 2569-2589, 2017. https://doi.org/10.1007/s10531-017-1372-2

EWEL, K. C.; CRESSA, C.; KNEIB, R.T.; LAKES, P. S.; LEVIN, L. A.; PALMER, M. A.; SNELGROVE, P.; WALL, D. H. Managing critical transition zones. Ecosystems, v. 4, n. 5, p. 452-460, 2001. https://doi.org/10.1007/s10021-001-0106-0

FOPPEN, R. P. B.; CHARDON, J. P.; LIEFVELD, W. Understanding the Role of Sink Patches in Source-Sink Metapopulations: Reed Warbler in an Agricultural Landscape. Conservation Biology, v. 14, n. 6, p. 1881-1892, 2000. https://doi.org/10.1111/j.15231739.2000.99022.x 
FRANCISCO, C. E. da S.; COELHO, R. M.; TORRES, R. B.; ADAMI, S. F. Análise multicriterial na seleção de bacia hidrográfica para recuperação ambiental. Ciência Florestal, v. 18, n. 1, p. 1, 2008. https://doi.org/10.5902/19805098506

GAMBA, C.; RIBEIRO, W. C. Conservação ambiental no Brasil: uma revisão crítica de sua institucionalização. Revista de Estudios Brasileños, v. 4, n. 6, p. 146-160, 2017. https://dx.doi.org/10.3232/REB.2017.V4.N6.2556

GOETZ, S. J. Remote sensing of riparian buffers: Past progress and future prospects. Journal of the American Water Resources Association, v. 42, n. 1, p. 133-143, 2006. https://doi.org/10.1111/j.1752-1688.2006.tb03829.x

GRÜBLER, A. Technology. In: MEYER, W. B.; TURNER, B. L. II. (Eds.). Changes in Land Use and Land Cover: A Global Perspective. Cambridge: Univ. of Cambridge Press, 1994. p. 287-328.

KELLY, J. M.; KOVAR, J. L.; SOKOLOWSKY, R.; MOORMAN, T. B. Phosphorus uptake during four years by different vegetative cover types in a riparian buffer. Nutrient

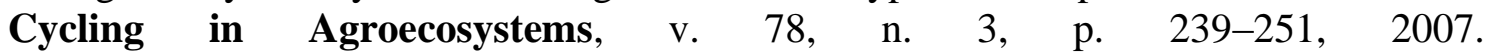
https://doi.org/10.1007/s10705-007-9088-4

KRONKA, F. J. N.; NALON, M. A.; MATSUKUMA, C. K. Inventário florestal da vegetação natural do Estado de São Paulo. São Paulo: Imprensa Oficial, 2005.

KUNTSCHIK, D. P.; EDUARTE, M.; UEHARA, T. H. K. Matas ciliares. São Paulo: SMA, 2011.

LEES, A. C.; PERES, C. A. Conservation Value of Remnant Riparian Forest Corridors of Varying Quality for Amazonian Birds and Mammals. Conservation Biology, v. 22, n. 2, p. 439-449, 2008. http://doi.wiley.com/10.1111/j.1523-1739.2007.00870.x

LIKENS, G. E.; BORMANN, F. H.; JOHNSON, N. M.; FISHER, D. W.; PIERCE, R. S. Effects of Forest Cutting and Herbicide Treatment on Nutrient Budgets in the Hubbard Brook Watershed-Ecosystem. Ecological Monographs, v. 40, n. 1, p. 23-47, 1970. https://doi.org/10.2307/1942440

LOVELAND, T. R.; ZHU, Z.; OHLEN, D. O.; BROWN, J. F.; REED, B. C.; YANG, L. M. An analysis of the IGBP global land-covercharacterization process. Photogrammetric Engineering and RemoteSensing, v. 9, n. 65, p. 1021-103, 1999.

MACHADO, C. J. S. Recursos hídricos e cidadania no Brasil: limites, alternativas e desafios. Ambiente \& Sociedade, v. 6, n. 2, p. 121-136, 2003. https://doi.org/10.1590/S1414753X2003000300008

MAGALHÃES, S. E. F.; PIMENTEL, R. M. de M. Matas ciliares - análise histórica dos estudos relacionados ao tema. Revista Brasileira de Geografia Física, v. 6, n. 1, p. 049057, 2013.

MARTENSEN, A. C.; PIMENTEL, R. G.; METZGER, J. P. Relative effects of fragment size and connectivity on bird community in the Atlantic Rain Forest: Implications for conservation. Biological Conservation, v. 141, n. 9, p. 2184-2192, 2008. https://doi.org/10.1016/j.biocon.2008.06.008

MARTINS, S. V. Recuperação de matas ciliares. São Paulo: Aprenda Fácil, 2001. 
MISERENDINO, M. L.; CASAUX, R.; ARCHANGELSKY, M.; DI PRINZIO, C.Y.; BRAND, C.; KUTSCHKER, A. M. Assessing land-use effects on water quality, in-stream habitat, riparian ecosystems and biodiversity in Patagonian northwest streams. Science of the $\begin{array}{lllllll}\text { total environment, } & \text { v. } 409, \quad \text { n. } 3, \quad \text { p. 612-624, }\end{array}$ https://doi.org/10.1016/j.scitotenv.2010.10.034

MOURA, A. M. M. De. Aplicação dos instrumentos de política ambiental no Brasil: avanços e desafios. In: IPEA. Governança Ambiental no Brasil: instituições, atores e políticas públicas. Brasília, DF, 2016. p. 111-145.

NIMER, E. Climatologia do Brasil. Brasília, DF: Secretaria de Planejamento da Presidência da República; Fundação Instituto Brasileiro de Geografia e Estatística; Diretoria de Geociéncias, Departamento de Recursos Naturais e Estudos Ambientais, 1989.

OLIVEIRA, L. C.; PEREIRA, R.; VIEIRA, J. R. G. Análise da degradação ambiental da mata ciliar em um trecho do rio Maxaranguape - RN: uma contribuição à gestão dos recursos hídricos do Rio Grande do Norte - Brasil. Holos, v. 5, n. 0, p. 49, 2011.

PARDINI, R.; DE BUENO, A. A.; GARDNER, T. A.; PRADO, P. I.; METZGER, J. P. Beyond the fragmentation threshold hypothesis: Regime shifts in biodiversity across fragmented landscapes. PLoS ONE, v. 5, n. 10, 2010. https://doi.org/10.1371/journal.pone.0013666

PEÑA, M. L. P.; MARQUES, R.; JAHNEL, M. C.; ANJOS, A. Dos. Respiração microbiana como indicador da qualidade do solo em ecossistema florestal. Revista Floresta, v. 35, n. 1, 2005. http://dx.doi.org/10.5380/rf.v35i1.2435

QGIS DEVELOPMENT TEAM. QGIS geographic information system. Beaverton, OR: Open Source Geospatial Foundation, 2020.

R CORE TEAM. R: A language and environment for statistical computing. Vienna, 2018.

RORIZ, P. A. C.; FEARNSIDE, P. M. A construção do Código Florestal Brasileiro e as diferentes perspectivas para a proteção das florestas. Novos Cadernos NAEA, n. 18, v. 2, p. 51-68, 2015. http://dx.doi.org/10.5801/ncn.v18i2.1866

SIMÕES, L. B.; RIBEIRO, F. L.; DAINESE, R. C.; CARDOSO, L. G.; CAMPOS, S. Priority areas for riparian forest restoration in southeastern Brazil. Scientia Forestalis, n. 61, p. 113-121, 2002.

SÃO PAULO (Estado). Decreto $\mathbf{n}^{\mathbf{0}}$ 61.183, de 20 de março de 2015. Acresce dispositivos ao Decreto $n^{\circ}$ 61.137, de 2015, que cria no âmbito da Administração Pública do Estado, o Comitê Gestor do Programa de Incentivos à Recuperação de Matas Ciliares e à Recomposição de Vegetação nas Bacias Formadoras de Mananciais de Água, instituído pelo Decreto n ${ }^{\circ}$ 60.521, de 2014. São Paulo: Secretaria de governo, 20 março 2015.

SÃO PAULO (Estado). Secretaria de Infraestrutura e Meio Ambiente. Resolução n ${ }^{\circ}$ 03, de 22 de janeiro de 1999. Dispõe sobre os procedimentos para o licenciamento ambiental de atividades minerárias. Diário Oficial [do] Estado, seção 1, v. 109, n. 16, 23 jan. 1999a.

SÃO PAULO (Estado). Secretaria de Infraestrutura e Meio Ambiente. Resolução n⿳0 28, de 22 de setembro de 1999. Dispõe sobre o zoneamento ambiental para mineração de areia no subtrecho da bacia hidrográfica do Rio Paraíba do Sul inserido nos municípios de Jacareí, São José dos Campos, Caçapava, Taubaté, Tremembé e Pindamonhangaba, e dá providências correlatas. 1999b. Available at: https://licenciamento.cetesb.sp.gov.br/legislacao/estadual/resolucoes/1999_Res_SMA_2 8.pdf. Access: Sep. 2020. 
TUCCI, C. E. M. Águas urbanas. Estudos Avançados, v. 22, n. 63, p. 97-112, 2008.

WICKHAM, H. Ggplot2: elegant graphics for data analysis. Houston: Springer, 2016. 